\title{
Definition of Globalization in the Context of European Integration
}

\section{A globalizáció meghatározása az európai integráció összefüggésében}

Globalization is perhaps the most frequently used yet least defined terms of our era. Theodore Levitt was the first to scientifically analyse the phenomenon in his study published in 1983; however, no one came up with a definition accepted by everyone to date. In addition to the introduction of scientific definitions, evolvement and the main branches of globalization, in this paper I attempt to present my own, scientific definition of the term that may serve as a useful working definition in the analysis of European integration.

Keywords: global integration, regional integration, integration of Europe, technological development

A globalizáció talán napjaink egyik legtöbbször idézett, mégis a legkevésbé definiált fogalmainak egyike. Theodore Levitt 1983-ban megjelent tanulmányában foglalkozott elöször tudományos alapon a jelenséggel, azonban mindenki által elfogadott fogalmának meghatározása még napjainkra sem zárult le. E tanulmányban a globalizáció föbb hétköznapi és tudományos fogalmának, fejlődéstörténetének, illetve föbb irányzatainak ismertetésén túl kísérletet szeretnék tenni egy olyan saját, tudományos fogalommeghatározásra, amely az európai integráció vizsgálata során is hasznos munkadefiníció lehet.

Kulcsszavak: globális integráció, regionális integráció, Európa integrációja, technikai fejlődés

Barna Szabó Major, Financial Investigator, National Tax and Customs Administration of Hungary, Criminal Affairs Directorate General, Central Investigation Division; doctoral candidate at the Hungarian University of Agriculture and Life Science Economic and Regional Sciences Doctoral School. Szabó Barna őrnagy, nyomozó, Nemzeti Adó- és Vámhivatal Bűnügyi Főigazgatósága Központi Nyomozó Főosztály; a Magyar Agrár- és Élettudományi Egyetem Gazdaság- és Regionális Tudományi Doktori Iskola doktorjelöltje. E-mail: szabo.barna@nav.gov.hu 


\section{Introduction}

Starting in the late $20^{\text {th }}$ century, integration has been playing a key role in global - and regional, including European - economy. However, integration - as we will see in the following chapters - cannot be isolated from the processes of globalization, global economy and world order. According to an increasingly widespread theory, regional integration is a regional structure of globalization. ${ }^{1}$ Furthermore, globalization can be interpreted in association with the world order, and the context of its application is global economy. ${ }^{2}$

Considering that - if the above concept is accepted - regional integration is nothing else than a regional structure of globalization, in my opinion, factoring in the processes of globalization when analysing European integration is unavoidable. In order to do this, clarification of the term of globalization is also essential. This is not an easy task, as, due to the relative novelty of the phenomenon, a scientific definition accepted by everyone is still not complete. Creation of a definition accepted by everyone is complicated further by the circumstance that its everyday use significantly differs from its scientific definition. However, this did not hinder globalization to become one of the most popular topics of media and public opinion. Moreover, shortcomings in the everyday interpretation even contributed to disputes concerning the topic.

To react to the following challenges, in addition to the introduction of the scientific term, evolvement and main branches of globalization, in this paper I attempt to present my own, scientific definition of the term that features the main characteristics of scientific definitions - primarily re-evaluation of the role of geographic locations, the integration mindset, and complexity - and may serve as a useful working definition in the analysis of European integration.

\section{Reference review}

\subsection{Laymen's definitions of globalization}

Creation of most of the widespread definitions describing globalization did not involve any scientific attention to detail; those merely phrase the description of everyday experiences. The characteristic they have in common is that most of them view the phenomenon from a single - and biased - point of view, without expanding the limits to understand the processes. These terms interpret globalization solely as the continuation of the earlier, already defined phenomena, only that these single phenomena observed in isolation are increasingly speeding up and operate on larger scales. ${ }^{3}$

Tibor Palánkai et al., A globális és regionális integráció gazdaságtana (Budapest: Akadémiai Kiadó, 2011), 14.

Mihály Simai, 'A globalizáció főbb tendenciái és kérdőjelei a XX. század végén', Tudományos Közlemények no 1 (2000), 9-10.

Zoltán Cséfalvay, Globalizáció 1.0. (Budapest: Nemzeti Tankönyvkiadó, 2004), 15.

Európai Tükör 2021/1. 
Scholte ${ }^{4}$ identified four ordinary groups of definitions, according to which, globalization:

1. is acceleration and intensifying of the internationalization of the world

2. global expansion of free market economy

3. universalization and cultural homogenization of the market

4. westernization, that is, expansion and spread of Western lifestyle patterns, primarily that of the United States, if necessary, even with the use of force.

According to Scholte, ${ }^{5}$ application of the four definitions will not lead anywhere, because the definitions based on these concepts will not provide any new views or added values that could not be described using already existing terms. Therefore, if globalization is mixed with terms such as internationalization, liberalization and universalization or westernization, we will never fully understand the phenomenon or be able to take a stance regarding the topic.

Unlike Scholte, Held et al., ${ }^{6}$ instead of basing his definition of the commonly used interpretation of globalization on current processes, used that of in the future. He argues - as shown in Figure 1 - that focusing on the openness of the economy and society, the commonly used interpretation of globalization and the discussions about the topic can be broken down in the following three groups:

1. According to the globalist or hyper globalist views, globalization is a series of completely new and radical changes that, in time, will lead to the emergence of a global society and economy comprising the whole world.

2. The sceptic view sees globalization merely as a stage - one of the many - in the history of humankind. Due to the increasing reaction of the nation states and national economies, it is not certain whether globalization will proceed in the present direction.

3. The transformational view represents an intermediary position between the above two concepts.

According to this view, globalization will bring about a whole series of changes and transformations, creating a new set of conditions for nation states and national economies and necessitating the creation of new roles for all stakeholders.

Though the commonly used interpretations of globalization amount for some of the most common definitions of the past and coming years, based on the above, it is easy to see that due to their unilateral approach, they may give rise to misuse, misleading and endless discussions. ${ }^{7}$

Jan Aart Scholte, What Is Globalization? The Definitional Issue - Again (United Kingdom: University of Warwick, 2002), 8-13.

Ibid. 13.

David Held et al., Global Transformations. Politics, Economics and Culture (Cambridge: Polity Press, 1999).

Ulrich Beck, Was ist Globalisierung? (Frankfurt: Suhrkamp, 1997), 26.

Európai Tükör 2021/1. 


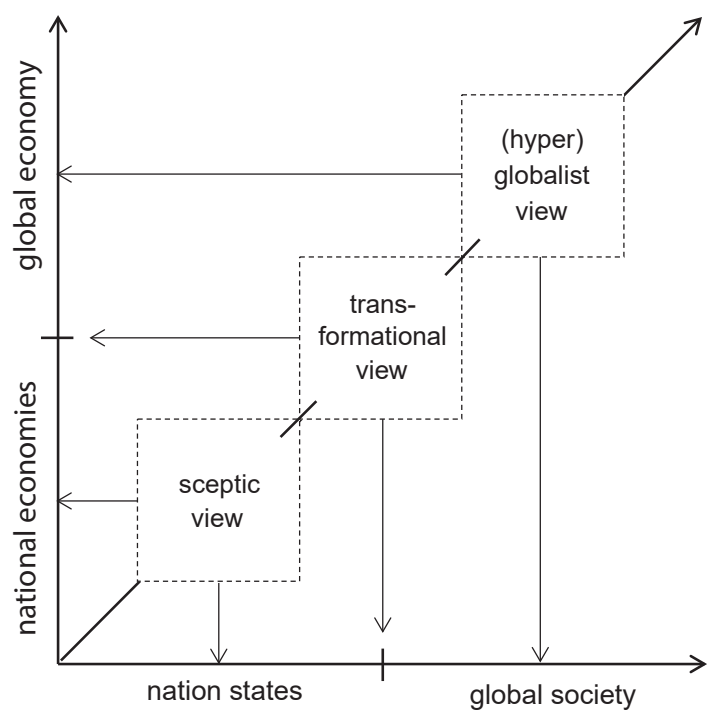

Figure 1

Basic points of view in the discussions regarding globalization

Source: Held et al. (1999)

I also share the opinion that views and discussions regarding globalization can only be fit in categories of globalist or sceptical, if some features of the term are arbitrarily highlighted and placed in the centre of the discussion or analysis. Globalization, however - as we will see below - is a sophisticated and complex phenomenon and establishment of its scientific definition is still ongoing today. Despite of the above, it is a fact that the phenomenon exists, and it is a necessary consequence of the economic, social and technological development starting in the mid-20 $0^{\text {th }}$ century. Therefore, it would make no sense to declare ex cathedra that globalization is good or bad. Scientific and substantiated establishment of the phenomenon's positive or negative impacts and evaluation of the efforts to influence those (for example, founding of international organisations) to establish the extent a given nation state uses the opportunities provided by globalization and handles, mitigates or avoids its negative effects may be more necessary.

\subsection{Scientific definitions of globalization}

We could see above that due to their biased views, commonly used definitions will not provide any new views or added values that could not be described using already existing terms. In Cséfalvay's ${ }^{8}$ point of view, compared to the common definitions, scientific definitions of globalization bring a significant quality change by re-evaluation of the role of geographical locations. Accordingly, globalization is:

$8 \quad$ Cséfalvay, Globalizáció 1.0, 65. 
1. integration, that is, an intensifying interconnection of the world's economies, societies and cultures expanding to increasing radiuses (regions)

2. a common dependence system, that is, interdependence between globally integrating geographical locations, economies, societies and cultures, expanding and reinforcing their geographical range

3. a process of networking that globally affects geographical locations and the economic-, social- and political players hosted by those

Scientific definitions - in Cséfalvay's ${ }^{9}$ point of view - though with varying significance, but do highlight the above three characteristics. Unlike common definitions, they regard local level transformation as part of the phenomenon exactly the same way as they do it with global changes.

In Beck's ${ }^{10}$ opinion, unlike common definitions, scientific definitions of globalization clearly distinguish the following three categories:

1. Globality as status, describing the progress rate of the economic, social, political and cultural integration of the world. It has to be noted that in this sense, though a little problematic, globality is still measurable with exact indicators. Measuring is possible at points where integration resulted in new global territorial units taking over from territorial units significant in previous eras.

2. Globalism as ideology, an ideology of omnipotence of the world market, in other words, neoliberalism. However, this limits the versatility of globalization to one field, that is, economy, and everything else, such as social, political and cultural fields are either subordinated to the global market or ignored.

3. Globalization as a process, which process is affected by globalism to a great extent, namely by the expansion of neoliberals' ideologies, yet it is more than that, as there is no guarantee that globalization will continue to evolve along these neoliberalist ideas.

Though some sources - for example Orbán ${ }^{11}$ - mention that the term of globalization first appeared in a lexicon published in English language in 1961, the majority of the references argue that the phenomenon of globalization was first discussed scientifically by Theodore Levitt in 1983. Levitt ${ }^{12}$ opines that many companies should disregard the painstakingly minute regional or national differences and should operate as if the world would be a large, global market.

Levitt's aforementioned statement was very much challenged, primarily within the marketing field, but researchers engaging in forecasting globalization argue that the variations of this theory will take over international markets. Though, we still cannot talk about a global consumer society today, the increasing cross-border mobility and electronic communication in the last few decades resulted in certain convergence, primarily in consumers' values. ${ }^{13}$

Ibid.

Beck, Was ist Globalisierung?, 26.

Annamária Orbán, 'Globalizáció, urbanizáció, fenntartható fejlődés', s. a.

Theodore Levitt, 'The Globalization of Markets', Harvard Business Review no 3 (1983), 92-102.

Annamária Sasné Grósz, 'A kulturális értékek, mint a globalizációs törekvések akadályai', 2004, 1-2.

Európai Tükör 2021/1. 
Since the publication of Levitt's above study, no unanimously accepted scientific definition was created for globalization, ${ }^{14}$ and systematic analysis of its basic characteristics was not conducted, either. ${ }^{15}$

Below I would like to introduce some scientific definitions through examples in a chronological order, taken from the professional discourse available to me:

1. Giddens ${ }^{16}$ opines that globalization is the increase of the intensity of the social relations encompassing the world, connecting remote locations in a way that events occurring in one place are affected by processes several thousand kilometres away, and vice versa

2. in Robertson' ${ }^{17}$ view, globalization is the "shrinking" of the world and a change of our mindsets, because we increasingly regard the world as a whole

3. Waters ${ }^{18}$ is positive that globalization is a social process, wherein the role of geographical limits in social and cultural phenomena is decreasing, and this process is also experienced by people as the decrease of the role of geographical limits

4. Bilton et al. ${ }^{19}$ argues that globalization is a process through which political, social, economic and cultural relations become increasingly global, resulting in far-reaching consequences in people's local and everyday lives

5. Held et al. ${ }^{20}$ proposes that globalization is the sum of the processes transforming the geographical organisation of the social relations and connections, creating transnational and interregional networks of activities, interactions and power

6. Gereffi ${ }^{21}$ observes that globalization is the integration and coordination of activities taking place in internationally different locations

7. Simai ${ }^{22}$ contends that globalization can be regarded as the sum of key processes of the late $20^{\text {th }}$ century, such as expansion of international flow of goods, services, money, capital, technology and information, and increase of the significance of those for national economies. Furthermore, globalization also includes intensifying of people's cross-border mobility, the importance of global economy orientation in commerce, fund investments and other transactions on company levels; geographical and institutional integration of markets, homogenization and standardization of production and consumption, harmonization of legal systems, emergence of more and more generally accepted international rules and norms in the wake of the activities of interstate organisations and cooperation systems

Cséfalvay, Globalizáció 1.0, 66.

David Held et al., Global Transformations (Cambridge: Polity Press, 2005), 1.

Anthony Giddens, The Consequence of Modernity (Cambridge: Polity Press, 1990), 64.

Roland Robertson, Globalization: Social Theory and Global Culture (London: Sage Publication, 1992$), 8$.

Malcom Waters, Globalization (London: Routledge, 1995), 3.

Tony Bilton et al., Introductory Sociology (London: Macmillan, 1996), 660.

Held et al., Global Transformations. Politics, Economics and Culture.

Gary Gereff, 'International Trade and Industrial Upgrading in the Apparel Commodity Chain', Journal of International Economics 48, no 1 (1999), 37-70.

Simai, 'A globalizáció főbb tendenciái', 9-10. 
8. Dollar ${ }^{23}$ maintains that globalization is an increasing integration of national economies and societies on Earth, propelled forward by the flow of goods, services, capital, people and information

9. Árva et al. ${ }^{24}$ proclaims that globalization, as opposed to the world's previously experienced economic and cultural homogenization processes, observed primarily along trade and its exchange routes, is a new, different development stage so far unknown; accordingly, he distinguishes some pre-globalization processes

10. Cséfalvay ${ }^{25}$ opines about globalization: it is an economic, social, political and cultural process, wherein: a) integration of geographical locations on Earth, and the companies, the social and political players operating in those locations will strengthen, and the geographical range of this integration will expand; $b$ ) parallel to the strengthening of integration, interdependence of geographical locations and players on that location is strengthening, while the geographical range is also expanding; c) in the wake of the strengthening of integration and interdependence, and with the expansion of the geographical range, global-scale economic, social, cultural and political networks emerge; d) this integration, interdependence system and networks are seen by social, economic and political players as a global change affecting everyday activities on a local scale, and vice versa, local everyday activities are affecting global processes

Palánkai ${ }^{26}$ emphasizes that the emergence of the Roman Empire or the discovery of America are regarded as globalization processes by many, however, the new characteristic structures of the globalization of our era are to be explained by the integration approach. In Palánkai's ${ }^{27}$ opinion, an increasingly widespread agreement has been reached regarding that globalization is nothing but a global integration structuring in regional integrations. Based on this, integration - may be present on a micro level in the form of trans-nationalization of companies, and on a macro level, in the form of regional- and global integration - is one of the basic dimensions of globalization processes. Below, I would like to present a few examples of scientific definitions based on this integration view:

1. Bhagwati ${ }^{28}$ proclaims that globalization is the integration of national economies into an international economy through commerce, direct foreign investment and short-term capital flow, generally through workers' and people's international movements and the flow of technology

$23 \quad$ David Dollar, Globalization, Poverty, and Inequality since 1980 (Development Research Group, World Bank, 2001), 2.

24 László Árvai and Bertalan Diczházi, Globalizáció és külföldi tôkeberuházások újabb fejleményei Magyarországon (Budapest: Kairosz Kiadó, 2002), 7.

Cséfalvay, Globalizáció 1.0, 66.

Palánkai et al., A globális és regionális integráció gazdaságtana, 9.

Ibid. 14.

Jagdish Bhagwati, In Defence of Globalization (New York: Oxford University Press, 2004), 3.

Európai Tükör 2021/1. 
2. Lechner ${ }^{29}$ contends that from several aspects, globalization is marked by economic integration, intentionally promoted by governments, companies and international organisations

3. Wolf ${ }^{30}$ expressed that globalization is an integration of business activities through the market, propelled by technological and political changes. Economic globalization results in cultural, social and political consequences;

4. Szentes ${ }^{31}$ states that globalization, more precisely, globalization in an economic sense is basically nothing but the process of the global economy's transformation into an integral system spreading to more and more countries, soon to include all. The global economy's transformation into an integral system - and the integral connection of any country with the world economy - usually means that players (or countries with other countries) are connected by a long-term and functional cooperation and interdependence

5. globalization is defined by The Economist ${ }^{32}$ as integration through the movement of goods, capital and workforce

6. Esze ${ }^{33}$ argues that globalization is a key characteristic of world economy; its basic dimension is global integration, structuring in regional integrations

7. Arató et al. ${ }^{34}$ opines regarding regional integrations - which phenomenon, as we saw, is a dimension of globalization - that historical and empire building integrations cannot be regarded as integration processes in today's sense, because those were done by military conquests, unlike regional integrations of our era, the definition of which is basically characterized by voluntary actions

8. Palánkai ${ }^{35}$ maintains that globalization is global integration, structuring in regional integrations

9. Ssáki $^{36}$ is convinced that globalization is a progress starting with the emergence of world economy as a whole, presented for us today in a more full-fledged form than ever. The basic hosts of globalization are not sovereign nation states but the integration of transnational groups. Globalization is mainly propelled forward by the technological development of transportation and electronic communication allowing for the creation and sustainment of workload sharing between remote worlds and dramatically decreased transaction costs of goods, people, capital, technologies and knowledge; on the other hand, organisational changes have made the global-scale flow of goods, capital, people and ideas easier through the market reforms.

Frank J Lechner and John Boli (eds), The Globalization Reader (Malden: Blackwell, 2005), 158.

Martin Wolf, Why Globalization Works (New Haven: Yale University Press, 2005), 19.

Tamás Szentes, 'Globalizáció, kölcsönös függések a világgazdaságban', in Világgazdaságtan, ed. by András Blahó et al. (Budapest: Akadémiai Kiadó, 2007), 31-32.

The Economist, 'Britain's Fallen Star', 21 February 2009, 57.

Magdolna Káldyné Esze et al., Integrálódó Európa (Budapest: Perfekt Gazdasági Tanácsadó, Oktató és Kiadó, 2009), 13.

34 Krisztina Arató and Boglárka Koller, Európa utazása - Integrációtörténet (Budapest: Gondolat Kiadó, 2009), 18.

35 Palánkai et al., A globális és regionális integráció gazdaságtana, 14, 29.

36 György Csáki, Nemzetközi gazdaságtan (Budapest: Napvilág Kiadó, 2017), 145, 148. 
However, it has to be noted that interpretation of globalization as a global integration is challenged by some theories. ${ }^{37}$ Contenders of the above view insist that integration itself is to be interpreted in a unique way, as it is not only an economic, but also a political merge, presuming a community feeling, a commonality, and the joint institutions of governance. Accordingly, the interpretation of globalization is inherently incomplete. ${ }^{38}$

Simai $^{39}$ also adds that regional integration can be a stage of globalization, but also, it can amount to an opposite process. In his view, globalization and regionalization is opposed by a further tendency: disintegration, which is the dissolution of larger units into smaller pieces.

\subsubsection{Summary of definitions of globalization}

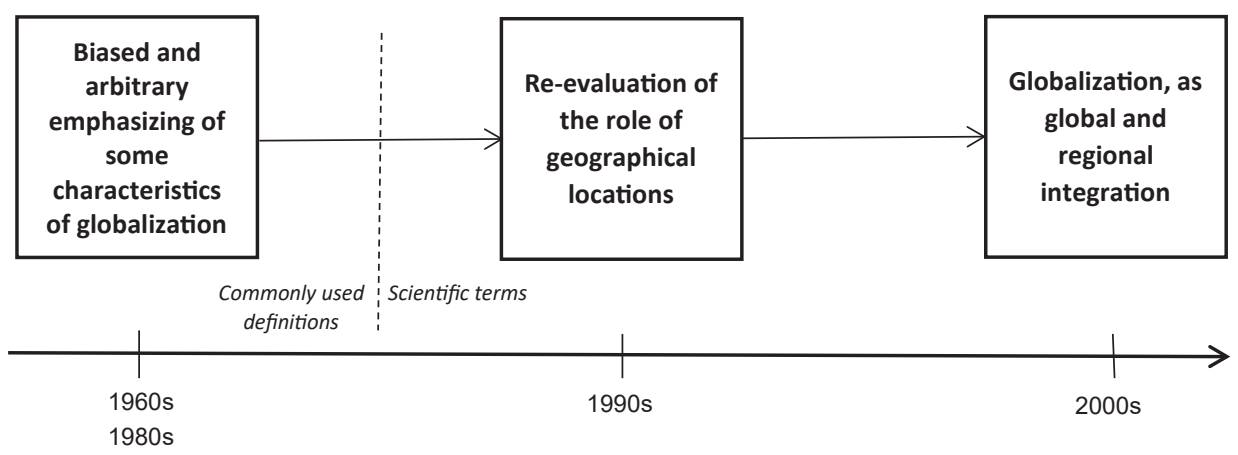

Figure 2

Evolving of definitions of globalization

Source: Compiled by the author based on Cséfalvay (2004), Palánkai et al. (2011)

As established above, globalization is a complex phenomenon, involving not only economic, but other, that is, social, political and cultural, and so on, dimensions. However, commonly used interpretations emphasize single characteristics thereof arbitrarily and in a biased way, and interpret the phenomenon as a continuation of these isolated characteristics accelerating in our era. Scientific definitions, however, place the role of geographical locations in focus, and they go beyond common interpretations by re-evaluating those roles. Though not unanimous, an increasingly widespread agreement has been reached regarding that globalization is nothing but a global integration structuring in regional integrations (Figure 2).

Palánkai et al., A globális és regionális integráció gazdaságtana, 34.

Held et al., Global Transformations, 28.

Simai, 'A globalizáció főbb tendenciái'. 


\section{Objectives}

If we accept the increasingly widespread concept detailed in the previous chapter, namely, that globalization is nothing but a global integration structuring in regional integrations, we cannot avoid taking globalization as a phenomenon into consideration in the analysis of European integration. This is complicated to a great extent by the circumstance that establishment of a definition of globalization accepted by everyone is still ongoing.

To respond to the above challenge, this study aims to define the term of globalization in a form that features the main characteristics published in the domestic and international references, and that can serve as a useful starting point in the analysis of European integration, primarily by answering the following questions:

1. What is European integration mainly propelled by?

2. Why is its onset estimated for the mid-20 $0^{\text {th }}$ century?

3. Why cannot historical integrations (for example, the Roman Empire) be regarded as part of the European integration processes in a sense used today?

\section{Material and methodology}

Meeting the above requirement, in the definition of the term globalization I applied the following methodology:

1. First of all, I conducted a research of professional discourse, the results of which are detailed in the review of references. In this process, amongst other things, I introduced the definitions available and published in domestic and international sources. 2. Following the above, I have selected the main characteristics of scientific definitions, the existence of which is - in my opinion - essential regarding the content of both the scientific and the above definition. 3. Out of these characteristics, I selected one main characteristic, and attempted to systematically analyse it, which, in the opinion of Held et al., ${ }^{40}$ is missing from scientific definitions - to re-emphasize its content and allow for the creation of a new (compared to the definitions shown in the references) and useful term that may be useful in the analysis of European integration. 4. Finally, I established the definition with integration and re-weighting of the elements - respective to the characteristics selected under points 2 and 3 - of the definitions introduced in the reference review.

Held et al., Global Transformations, 1. 


\section{Results}

\subsection{Characteristics selected during the creation of the definition}

Considering the above objectives and methodology, based on the definitions introduced in the reference review, I emphasized five characteristics during the definition of the term, namely:

1. Scientific definitions of globalization clearly distinguish globalism, as a status from globalization as a process, and globalism as an ideology. ${ }^{41}$

2. Globalization is a complex phenomenon, involving not only economic, but also social, political, cultural dimensions. ${ }^{42}$

3. Globalization provides a new view compared to commonly used definitions by the evaluation of the role of geographical locations. ${ }^{43}$

4. The content of globalization is global integration, structuring in regional integrations. ${ }^{44}$ Scientific definitions regard local level transformations as part of the phenomenon the same way as they do it with global changes ${ }^{45}$ Furthermore, it is important to note that the regional integration processes of our era - unlike historical, empire building integrations - are voluntary. ${ }^{46}$

5. Amongst other things, globalization is propelled by the development of technology, ${ }^{47}$ and within this, primarily information technological development. A dimension of information technological development as a technological development propelling globalization is introduced by Simai, ${ }^{48}$ where the author explains that one of the elements of technological development is this interactive connecting dimension propelling globalization through the flow of telecommunication, computers and information, which also allows for the continuous analysis of data.

Beck, Was ist Globalisierung?, 26.

Bilton et al., Introductory Sociology, 660; Cséfalvay, Globalizáció 1.0, 66; Dollar, Globalization, Poverty, and Inequality since 1980, 2; Held et al., Global Transformations. Politics, Economics and Culture; Simai, 'A globalizáció főbb tendenciái', 9-10; Wolf, Why Globalization Works, 19.

43 Cséfalvay, Globalizáció 1.0, 65.

44 Káldyné Esze et al., Integrálódó Európa, 13; Palánkai et al., A globális és regionális integráció gazdaságtana, $14,29$.

45 Cséfalvay, Globalizáció 1.0, 65.

$46 \quad$ Arató and Koller, Európa utazása - Integrációtörténet, 18.

47 Csáki, Nemzetközi gazdaságtan, 145, 148; Wolf, Why Globalization Works, 19.

48 Simai, 'A globalizáció főbb tendenciái', 13. 


\subsection{The main characteristics selected during the creation of the definition and the result of systematic analysis}

The fifth characteristic selected during the creation of the definition, namely that amongst other things, globalization is propelled by the development of technology, and within this, primarily information technological development is one I deemed necessary to highlight, due to the following.

As seen above, Dollar ${ }^{49}$ maintains that global integration is propelled forward by the flow of goods, services, capital, people and information. Though based on other criteria, these are the factors that appear in the definitions published by Bhagwati, ${ }^{50}$ Csáki, ${ }^{51}$ Simai ${ }^{52}$ and The Economist. ${ }^{53}$ If this concept is accepted, it becomes clear that to the global or at least transcontinental flow of the above factors shaping globalization require an adequate technical infrastructure, completed by information technology.

Technological development of goods, services and persons goes back to historical eras. Starting with the $2^{\text {nd }}$ century B.C., for example, merchants transported the majority of their products from China to Europe via the so-called Silk Way leading through some areas in Asia and North Africa. From the late $15^{\text {th }}$ century to the late $18^{\text {th }}$ century, that is, in the Age of Discovery, Western European civilization reached areas of the Earth beyond the reach of the Silk Way, for example, the continent of America at sea. In this era, transportation was done by road vehicles powered by humans or animals or watercraft powered by humans or the wind. The ultimate breakthrough only happened later, in the $18^{\text {th }}$ century, when James Watt created the first steam machine in 1769 , paving the way for the emergence of railway networks, and steamships, which became widespread by the $19^{\text {th }}$ century, significantly speeding up transportation. A further progress was induced by Nikolaus August Otto's invention of internal combustion engine in 1876, application and further development of which facilitated the emanation of road-, maritime- and air transport in the sense we use today.

Regarding the global flow of goods and services, it has to be noted that an increasing proportion thereof is dematerialized and/or can be digitalized, therefore, their delivery can be done online, supplementing traditional, costly and time-consuming channels. Such goods or services are for example intellectual properties (books, music, movies, software, and so on), patents or education. Virtual, online environment (for example, webshop) may also increase the flow of products and services that can only be delivered through traditional channels. Shifting of delivery channels or parts thereof towards online platforms results in a decrease of the significance of the flow of persons.

Dollar, Globalization, Poverty, and Inequality since 1980, 2.

Bhagwati, In Defence of Globalization, 3.

Csáki, Nemzetközi gazdaságtan, 145, 148.

Simai, 'A globalizáció fôbb tendenciái', 9-10.

The Economist, 'Britain's Fallen Star', 57.

Európai Tükör 2021/1. 
Capital is a long-term cash investment or other material or intellectual goods. In terms of its materialization form, cash capital is nothing but cash, that is, a general means of exchange, useable for purchasing products or services. If we study capital, as a factor shaping globalization, though with some simplification, it is practical to focus on cash capital and expand our study to cash as a means of exchange (hereinafter jointly: money). In my opinion, other material- or intellectual capital flows through the above delivery and information flow methods introduced above, and such flow of goods and services assumes the flow of money as an exchange in the opposite direction.

Initially, the flow of money did not differ from that of the goods in a traditional sense, which is cumbersome, and from a security point of view, very risky. The solution to this problem was offered by the introduction of bank accounts, allowing for the partial, later the complete break from the risky traditional money transfer methods. Origo ${ }^{54}$ informs that bank accounts were used as early as the ancient ages for the safekeeping of money, however, bank accounts supporting payment methods requiring interconnected banks, for example, wire transfer, have only been available since the 1920s, and did not become common until the 1950s. Though the first ATM machine was set up in 1959 in the United States, money transfers did not fully become independent from the flow of goods, services and persons until the 1990s to facilitate smooth global cash flow.

Flow of oral or written information between persons could only be effected using traditional means of delivery until 1876, when Alexander Graham Bell invented the telephone. However, telephone communication was initially very expensive and cumbersome, as the devices were stationary, and their wired connection also involved telephone centres. In the 1980s, the first wireless mobile phones appeared, and by the 1990s, they became widespread and made the flow of oral communication significantly easier. ${ }^{55}$

Historically, written communication was done by a courier or mail service. Like in case of oral information flow, the breakthrough waited until the $19^{\text {th }}$ century, when Samuel Morse patented his first spark telegram. This allowed the immediate transmission of "Morse" codes to long distances. As a further development of the telegram, Telex was created in Germany in 1926, which, by the late 1980s, prevailed in electronic text transmission. Telex was able to transmit full texts, without the necessity of Morse codes. In addition to telex, in the mid-1970s, telefax appeared, which became common in the 1980s. Telefax - though paper only - was capable of the transmission of formatted text and simple figures. ${ }^{56}$

A real breakthrough in the flow of both oral and written information was the spread of Internet, namely that online IT applications merged the flow channels of both communication option.

Origo, 'Bankszámlatöri, hogy ne kapjon egyest', 01 November 2016.

Sándor Forgó, Médiaismeret (Eger: BVB Nyomda és Kiadó Kft., 2010), VI.6.3.

Lajos Hangodi, 'A balassagyarmati vezetékes hírközlés technikatörténete: telegráf - távíró és telefon - távbeszélő', s. a., 13. 


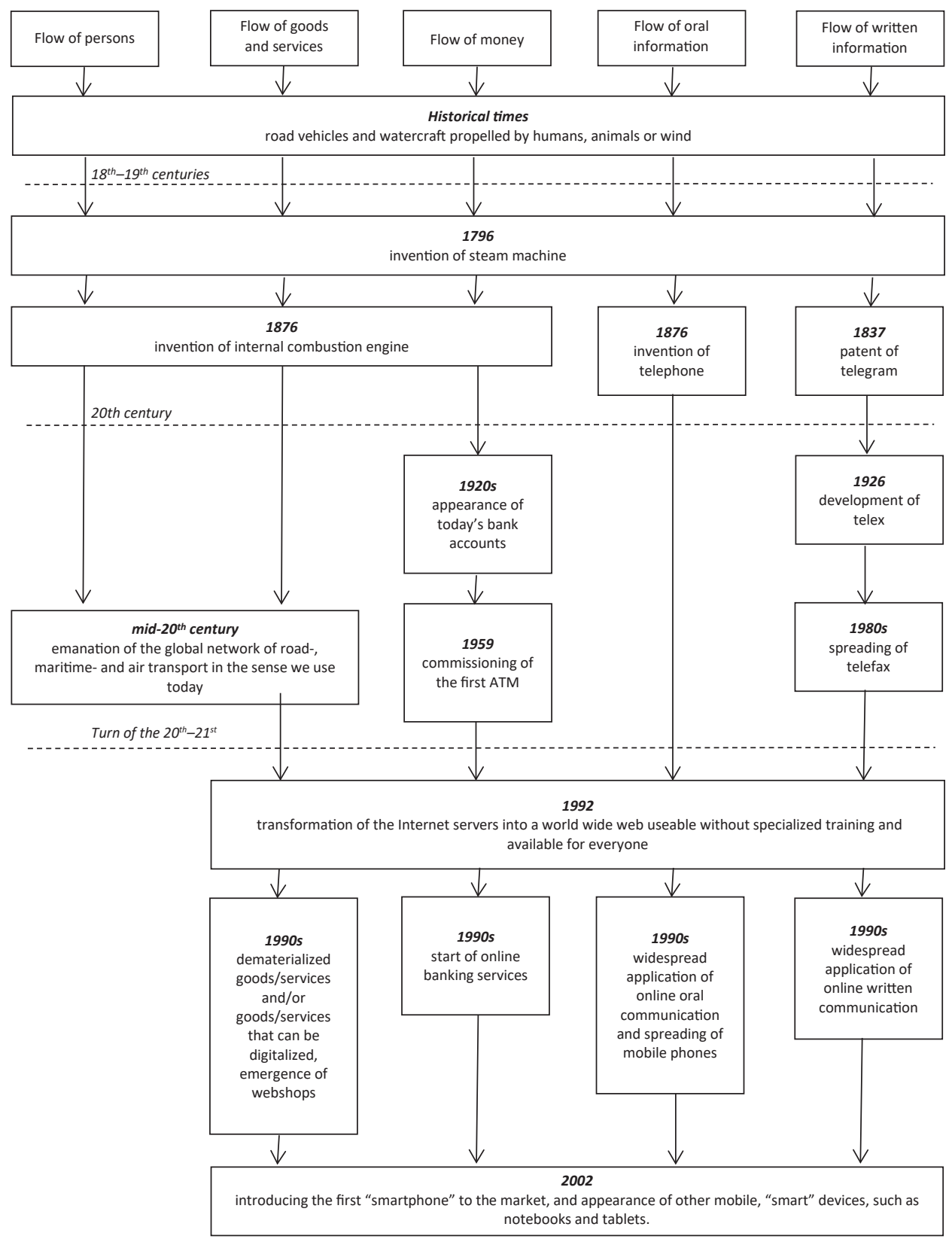

Figure 3

Evolvement of the flow of factors shaping globalization

Source: Compiled by the author based on Dollar (2001) 
As we could see above, in the development of the flow of goods, services, money and information, the ultimate breakthrough - as an analogy to the industrial revolution of the $18^{\text {th }}-19^{\text {th }}$ centuries - was represented by the Internet. The history of Internet started in the 1960s, however, transformation of Internet servers into a world wide web useable without specialized training and available for everyone did not happen until $1992 .{ }^{57}$ Smartphone, as we use today, appeared on consumers' market in $2002 .{ }^{58}$ In the meantime, the use of the World Wide Web reached its peak with the feature of the increasingly widespread mobile "smart" devices, such as notebooks, tablets and telephones able to connect to the Internet, both in terms of everyday life and the flow of studied factors shaping globalization.

If we accept the above reasoning, it becomes clear that the prerequisite of globalization is the flow of goods, services, capital, people and information. The technological conditions necessary for this, as demonstrated by Figure 3, have emerged by the mid$20^{\text {th }}$ century, and later, the Millennium brought a significant change by the spreading of Internet and the connection of mobile, "smart" devices to the web.

\subsection{Results of the creation of the definition}

Based on the interpretations detailed in the reference review and considering the objective of my study, emphasizing and re-iterating the five main characteristics introduced in Section 4, I created the following working definition:

Globalization is the voluntary, regionally structured global integration of economic and other phenomena and processes, primarily facilitated by the technical, primarily information technological development - or the sum of the associated ideologies.

Based on the above definition, in line with the selected five main criteria, globalization is:

1. a status (phenomenon), a process and an ideology

2. the most significant feature of which is complexity, involving not only economic, but also social, political, cultural dimensions

3. these dimensions connect to each other on a geographical basis

4. and this geographical interconnection, that is, integration, interpretable on both global and regional level, is voluntary

5. and development thereof is facilitated by technological, precisely information technological development

Sure enough, the scientific definition of globalization may also include the creation of other definitions meeting the substantive requirements of modern globalization terms, or even exceed them. In my opinion, the above definition may serve as a useful working definition in the examination of European integration, as it answers the questions established in the objectives, namely that European integration - which can be interpreted as a local structure of global integration - is mainly propelled forward by technological development (answer 1). By the mid-20 $0^{\text {th }}$ century, technological development matured

57 Tamás András Bartal, 'Az Internet története', 2004.

58 Bence Kolmer, 'Az okos eszközök megjelenése mindennapi életünkben', 2014.

Európai Tükör 2021/1. 
enough to facilitate the global-scale flow of factors shaping globalization, and following the Millennium, taking advantage of the development of information technology, primarily Internet, the flow of these factors entered into a new dimension (answer 2). Previous, historical integration efforts - for example, the Roman Empire, France at the time of the revolutionary wars led by Napoleon, the Austro-Hungarian Empire, or even the Germany of WW II - cannot be regarded as part of the European integration in today's sense, as those resulted from military conquests, as opposed to voluntary, international treaties (answer 3).

\section{Conclusion}

Last but not least, I am intending to demonstrate the usability of the defined globalization term in the context of European integration, in the wake of the European Union and other European sub-regional integration efforts. However, to do this, it is necessary to extract the definition of regional integration out of the working definition, using the following 4 main characteristics:

1. Globalization and regional integration are interconnected. Regional integration is nothing but globalization, namely a regional structure of global integration. 2. Regional integration is voluntary - primarily resulting from economic interests - as opposed to the empire building conquests of historical eras. 3. Regional integration - considering that it is a local structure of global integration - was also inspired by the technological developments of the mid- $20^{\text {th }}$ century, and within this, primarily the information technological development after the Millennium. 4. As established above, the working definition of globalization also allows for the establishment that regional integration is a complex phenomenon, involving not only economic, but also other social, political and cultural dimensions.

\subsection{Working definition of globalization in the wake of the development of the integration of the European Union}

The impact of global events on European integration (main characteristic 1) goes back to World War II ending with the victory of the Allied Forces - the United States, the United Kingdom, France and the Soviet Union. Due to the losses induced by the war and the collapse of their colonization system, the economy of the United Kingdom and France went through a recess, whereas the United States and the Soviet Union transformed into superpowers. It is no surprise that in the "wounded" Europe, the idea of a European alliance gained traction, because it was seen by many as an opportunity to regain Europe's influence to offset the United States and the Soviet Union. ${ }^{59}$ Promotion of a cooperation between Western European countries was also the interest of the United States, considering which, upon

59 Bence Kurya, A multipoláris világrend fejlődése, kialakulása, és jövốje (Miskolc: Miskolci Egyetem, 2014), $4-5$. 
the recommendation of their Secretary of State, George C Marshall, they implemented the European Recovery Program - more widely known, the Marshall Plan - and founded the Organization for European Economic Co-operation (OEEC) initially comprising 16 member states, paving the way to future integration efforts. ${ }^{60}$

After World War II, inclusion of the idea of a European integration in international treaties and implementation thereof, as explained below, is mainly motivated by economic interests, as opposed to an external duress or threat (main characteristic 2). Namely, in this era, the majority of European countries has arranged for a protectionist commerce policy to protect domestic production. However, protectionism isolates national markets from each other, resulting in the decline of opportunities offered by wide markets and the advantages of large-scale operation. Liberalization forming part of economic integration however eliminates isolation of markets, as relatively small and middle-sized national markets - based on the institutional construction of the four basic freedoms, that is, the free movement of goods, services, persons and capital - integrate into a large continental market. ${ }^{61}$

In my opinion, knowledge regarding the phases of integration, such as the stages requiring market-, economic- and political processes is essential in the study of the development of European integration (main characteristic 3). Based on Balassa's ${ }^{62}$ classic, these stages are the following:

1. Free trade zone, wherein member states liberalize the flow of products and services by reducing tariffs and quotas, but each state applies separate national tariffs and quotas towards third countries.

2. Customs union, being a development of the free trade zone in the sense that within the framework of the community foreign affairs policy, member states apply unified tariffs towards third countries.

3. Common market: within the zone, in addition to freeing up the movement of goods and services, the movement of workforce and capital is also liberalized.

4. Single market, which is realized by the full elimination of not only tariffs, but also non-tariff restrictions. Please note that Balassa's classification did not contain the last stage. ${ }^{63}$

5. On the level of economic union, in addition to the above, economy politics are also integrated. If a community currency is also implemented, a monetary union is established.

6. The highest form of integration is a political union, wherein governance and legislation is also integrated under a community umbrella.

However, it has to be noted that Balassa's classification is primarily usable for the purposes of analysis. In practice, however, many transitional and mixed forms exist, and European integration did not evolve along these lines, either. ${ }^{64}$

Palánkai et al., A globális és regionális integráció gazdaságtana, 49.

Péter Halmai, Krízis és növekedés az Európai Unióban (Budapest: Akadémiai Kiadó, 2014), 52.

Béla Balassa, The Theory of Economic Integration (Homewood, Illinois: Richard D. Irwin, 1961), 2.

Palánkai et al., A globális és regionális integráció gazdaságtana, 39.

Mihály Simai, 'Globalizáció és regionális együttmúködés a XXI. század elején', in Európai integrációs alapismeretek, ed. by András Blahó (Budapest: Aula Kiadó, 2003), 56.

Európai Tükör 2021/1. 
Poets, writers and philosophers envisioned European integration as early as the medieval ages. Victor Hugo wrote about the vision of a United States of Europe, which vision remained within the circles of the intellectual elite until the $20^{\text {th }}$ century ${ }^{65}$ Following World War II, on 19 September 1946, in his Zurich speech, Churchill emphasized that a United States of Europe should be founded, with France and Germany in the lead, but available for any European country intending to access. ${ }^{66}$ In terms of practical realization of European integration, the execution of the Treaty of Rome on 25 March 1957 by France, the German Federation, Italy and the Benelux States has proved to be a historical development. The European Economic Community was formed within the framework of this treaty. This community united in 1967 through the European Coal and Steel Community (Montanunion) for the community control of coal mining and steel industry and the pacific use of nuclear energy and through the European Atomic Energy Community (EURATOM), continuing their activities under the name of European Communities. In 1993, the institution system of the European Communities transformed into the European Union, as we know today. The main objective of the European Economic Community was a comprehensive economic integration, which they intended to realize by the implementation of a tariff union and a common market, starting from 1 January 1958. As of 1 July 1968, customs union, and simultaneously, the program of the common market have been realized. Until the early 1970s, these market conditions provided beneficial integration processes. However, crises unravelling early into the decade served as a warning regarding the shortcomings of integration, as governments attempted to remedy their internal problems by applying non-tariff measures to the detriment of integration partners. To solve this, the Committee prepared a so-called White Book for the summit of June 1985, a gathering of heads of states of European Communities, setting about 300 exact goals to create a single market, the realization deadline of which was aimed for the $31^{\text {st }}$ of December 1992. Though not without fail, but the plan of a single market, has largely been realized until the established deadline. However, this single market continued to show shortcomings in several fields, attributable to the lack of a common economy policy and common currency. The Committee has committed to an economic and monetary union as early as 1962, and drafted various plans for implementation. During the summit held in Maastricht in December 1991, the Delors Plan published in April 1989 was accepted, wherein, implementation of the monetary union was foreseen in three stages, in the 1990s. As a result, the single currency, that is, Euro, as an actual account money was implemented on 1 January 1999 in 11 member states, and on 1 January 2002, it appeared in the form of cash (notes and account money), in 12 member states. ${ }^{67}$ As I am writing this, 19 member states of the European Union of 28 member states are part of the monetary union, that is, the Eurozone. ${ }^{68}$

\footnotetext{
65 Jenő Horváth, 'Az európai integráció története: 1945-2000’, in Európai integrációs alapismeretek, ed. by András Blahó (Budapest: Aula Kiadó, 2003), 67.

66 Jenő Czuczai and Lajos Ficzere (eds), Európa A-tól Z-ig (Budapest: Eötvös Lóránd Tudományegyetem, 1997), 3.

67 Palánkai et al., A globális és regionális integráció gazdaságtana, 50-62.

68 European Commission, 'What is the euro area?', 2019.
} 


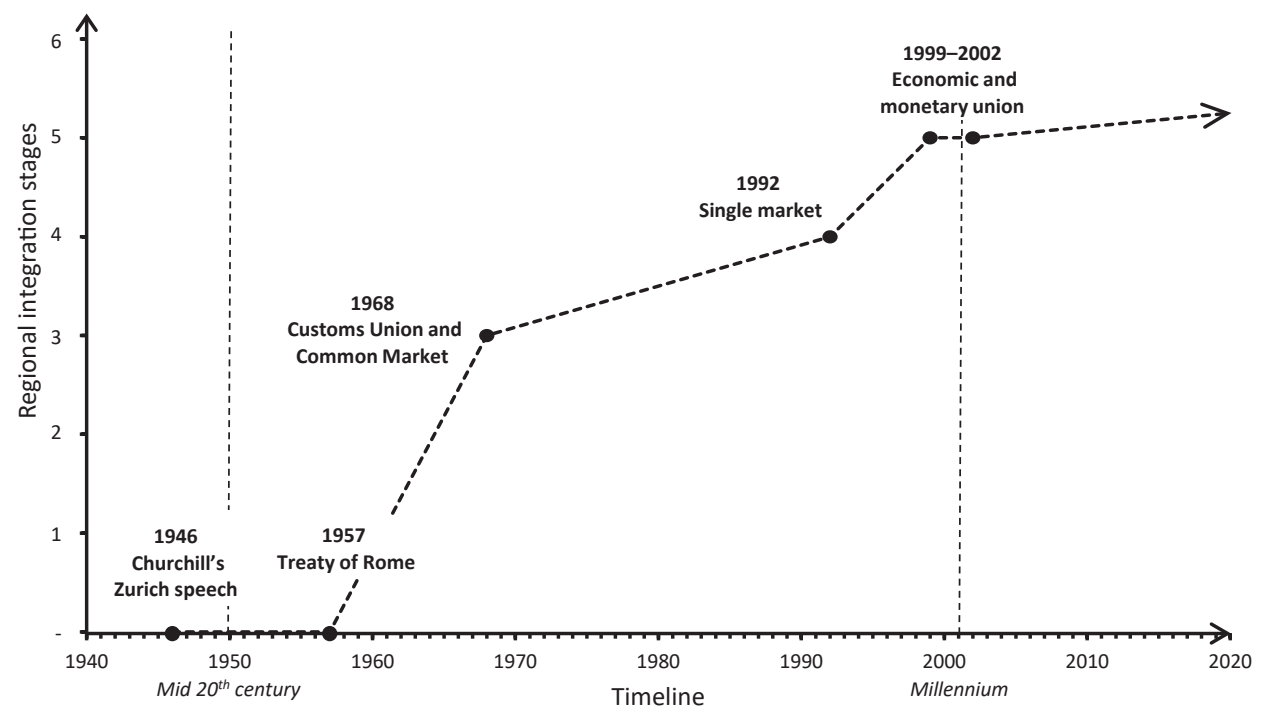

Figure 4

Development of the integration of the European Union according to Balassa's integration stages

Source: Compiled by the author based on Czuczai and Ficzere (1997) and Palánkai et al. (2011)

The above - as shown in Figure 4 - make it clear that in line with the working definition, the onset of the European Union's integration processes is estimated for the mid-20 th century, and around the Millennium, it jumped to further levels of integration.

Finally, it has to be emphasized that though the European Union is primarily an economic integration, its activities also cover other fields (main characteristic 4 ). The Lisbon Treaty, the current founding treaty of the integration, effective as of 1 December 2009, defines the types of competencies and fields of the European Union. These fields cover not only economic competencies, but also cover environment protection, public health care, culture, education and space research. ${ }^{69}$

\subsection{Working definition of globalization in the wake of the development of the European sub-regional integration}

\subsubsection{European sub-regional integrations}

Though a significant portion of the European integration is covered by the evolvement of the European Union, other sub-regional integration efforts also appeared, out of which, the following have to be mentioned:

69 Ákos Kengyel, 'Az Európai Unió politikái', in A globális és regionális integráció gazdaságtana, ed. by Tibor Palánkai et al. (Budapest: Akadémiai Kiadó, 2011), 218-219. 


\subsubsection{Organisation for Economic Co-operation and Development (OECD)}

The Marshall Plan developed to boost European economies declining after World War II, and the Organisation for the European Economic Co-operation (OEEC), founded for the implementation of the former attained their goals, opening up new possibilities in the economic cooperation between member states. Continuation of the cooperation, and - with the accession of the United States and Canada - lifting it into a global level resulted in the creation of the Organisation for Economic Co-operation and Development (OECD) in 1960, currently consisting of 36 member states, out of which, 27 European countries (except for Iceland, Norway, Switzerland and New Zealand) are also a member of the European Union. ${ }^{70}$

\subsubsection{European Free Trade Association (EFTA)}

Integration efforts of the European Economic Communities were seen as a threat to economic interests of outsider Western European countries. To offset the impacts, in 1960, 7 states, namely Austria, Denmark, the U.K., Norway, Portugal, Switzerland and Sweden founded the European Free Trade Association, which was later accessed by Finland, Iceland and Liechtenstein. EFTA is a free trade zone, which, in terms of its Scandinavian member states, features common market elements by the freedom of capital movement and partial liberalization of movement of workforce. Considering that the majority of its member states left the association and joined the European Economic Community and the European Union, the number of EFTA members is down to 4 countries, namely Iceland, Norway, Switzerland and Liechtenstein. ${ }^{71}$

\subsubsection{European Economic Area (EEA)}

Aims to expand the internal market of the European Union to EFTA, considering that these countries did not intend to or did not join the European Union. The treaty founding the EEA entered into force in 1994. It has to be noted that Switzerland, as an EFTA member state also signed the treaty, however, after a rejecting referendum, it did not ratify it. Subsequently, Switzerland entered into bilateral agreements with the European Union to preserve economic integration. ${ }^{72}$

\subsubsection{Integration efforts of the European countries of the former Comecon}

The relation of the Council for Mutual Economic Assistance (CMEA, CEMA or Comecon) consisting of socialist countries and the European Economic Community/European

OECD, 'Organisation for Economic Co-operation and Development', 2018.

Palánkai et al., A globális és regionális integráció gazdaságtana, 51-52.

Krzysztof Bartczak and Fernando Garcés de los Fayos, 'The European Economic Area (EEA), Switzerland and the North', 2018. 
Communities was characterized by reciprocal non-recognition. However, after the dissolution of the Soviet Union and Comecon, several bilateral free trade agreements were entered into by former member states, motivated by the efforts to fill the void after the cessation of former commercial relations and preparation for the accession to the European Union. The first agreement of this kind was the Central European Free Trade Agreement (CEFTA), entered into by Czechoslovakia (later: the Czech Republic and Slovakia), Poland and Hungary (called the Visegrád Countries after their history) and entered into force in 1993. It aimed the realization of a free trade zone based on bilateral agreements, with the deadline of $2001 .^{73}$ The agreement was accessed by Slovenia in 1996, and later by Romania, Bulgaria, Croatia and Macedonia. Joining was conditioned to - amongst other things - entering into a free trade agreement with CEFTA member states and an accession agreement with the European Union. Considering that except for Croatia and Macedonia, by 2007, all countries have joined the European Union, they decided to expand towards the Balkan states remaining outside, namely Albania, Bosnia and Herzegovina, Kosovo, Moldova, Montenegro and Serbia. ${ }^{74}$ Considering that Croatia joined the European Union in 2013, at the time of writing this paper, the number of CEFTA member states was reduced to 7. Out of the integration efforts of the former European Comecon countries, the Baltic Free Trade Agreement (BAFTA) is worth mentioning, entered into in 1994 by Estonia, Latvia and Lithuania. It aimed the realization of free trade of industrial products, which was extended to agricultural products and food in 1997. Considering that in 2004, every member state joined the European Union, the Agreement was dissolved. ${ }^{75}$

\subsubsection{The definition of globalization and the European sub-regional integrations}

The above European sub-regional agreements vividly demonstrate the European Union's dominance within the European integration, as the majority of member states of the above treaties, for example, the former member states of BAFTA and CEFTA has joined the EU by today, or, as is the case of the current CEFTA member states, this is their intention. Of course, we have seen states, who - for example, Switzerland - though wish to benefit from the advantages of economic integration, however, instead of joining the EU (for various political and social reasons), they intend to realize this by bilateral agreements.

If we want to apply the working definition of globalization, more precisely, the 4 main characteristics of regional integration derived therefrom in the context of European sub-regional integrations, the correlation with global event is obvious (characteristic 1). Due to the bipolar world order emerging after World War II, an economic integration between Western European integration bodies belonging to the scope of interests of the United States (OEEC, European Economic Community, OECD) and Eastern European Comecon countries belonging to the scope of interests of the Soviet Union was ruled out. However, following the disintegration of the Soviet Union and Comecon

Palánkai et al., A globális és regionális integráció gazdaságtana, 63, 66-67.

Zsófia Molnár, 'Közép-európai Szabadkereskedelmi Megállapodás', 2013.

Sandro Steinbach, 'Baltic Free Trade Agreement', 2012.

Európai Tükör 2021/1. 
in the early 1990s, Eastern European former communist countries started economic cooperation (for example, CEFTA, BAFTA), and their gradual - in the case of CEFTA, still ongoing - accession to the European Union.

The voluntary nature of the evolving of the European Union based on economic interest also applies to European sub-regional integrations (main characteristic 2). Concerning countries left out of the economic cooperation of the Western countries (OEEC, OECD) and the integration processes of the European Economic Community, the European Communities and the European Union for various reasons (EFTA, EEA), the primary motives were the benefit from the advantages of integration. Eastern countries (CEFTA, BAFTA) aimed to fill the economic void left after the disintegration of the Soviet Union and Comecon and to prepare for the accession to the European Union.

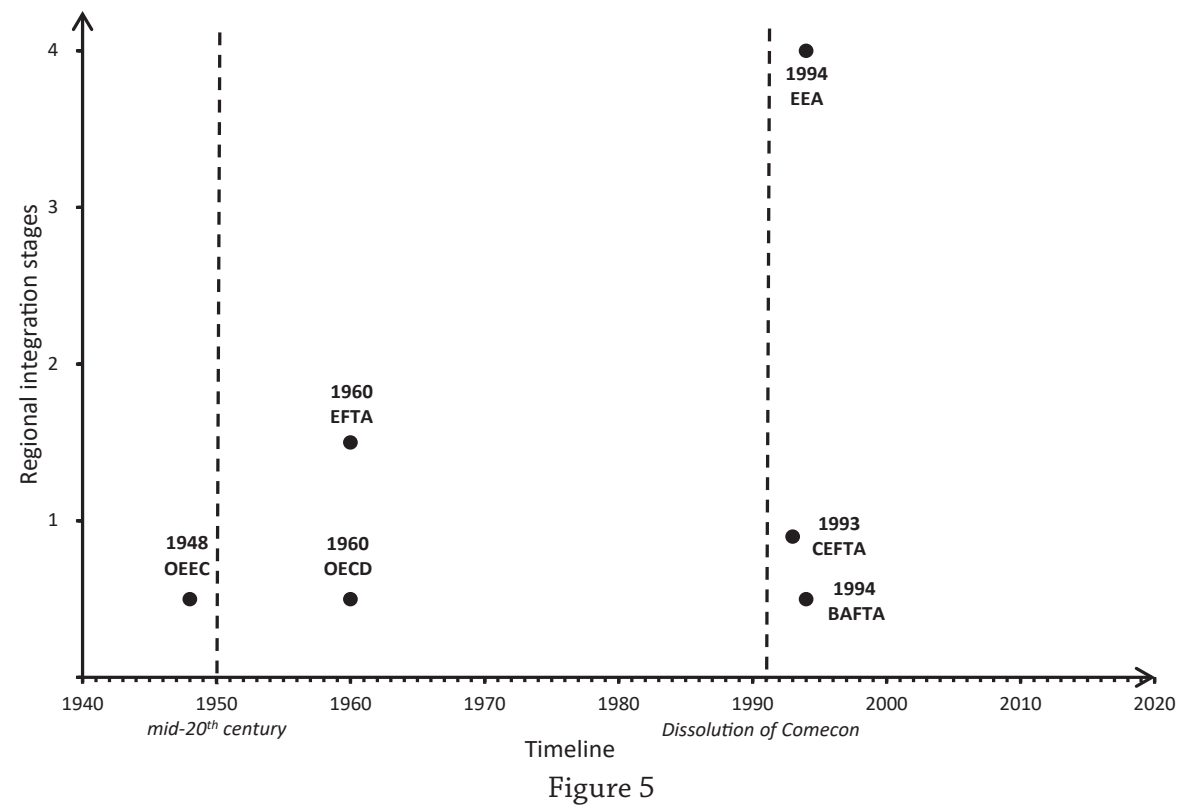

Materialization of major sub-regional co-operations in Europe according to Balassa's integration stages Source: Compiled by the author based on Bartczak and Garcés de los Fayos (2018), Molnár (2013), OECD (2018), Palánkai et al. (2011) and Steinbach (2012)

As shown in Figure 5, the above sub-regional integrations materialized in the mid-20 $0^{\text {th }}$ century and around the Millennium, however, the primary reason for this was the intention of the European integration dominated by the development of the European Union and the disintegration of the Eastern pole of around the early 1990s. Considering the European Union's key role in European integration, if not directly, but based on the rationale detailed in Section 6.1, it is indirectly inferable that the processes were propelled by the technological development of the mid- $20^{\text {th }}$ century, primarily the information technological development after the Millennium, and, in addition to the economic aspects, integration processes also affect social, political and cultural processes (main characteristics $3-4)$. 


\subsection{Summary of conclusions}

If we accept the working definition of globalization under Section 5.3 and the 4 main characteristics of regional integration under Section 6, regarding the European Union, it can be established that the working definition's main characteristics regarding regional integration show a correlation with the integration processes already completed, which finding can also be directly or indirectly applied in terms of European sub-regional co-operations.

Considering the above, the working definition of globalization can also be interpreted in the context of European integration.

\section{References}

Arató, Krisztina and Boglárka Koller, Európa utazása - Integrációtörténet. Budapest: Gondolat Kiadó, 2009.

Árvai, László and Bertalan Diczházi, Globalizáció és külföldi tőkeberuházások újabb fejleményei Magyarországon. Budapest: Kairosz Kiadó, 2002.

Balassa, Béla, The Theory of Economic Integration. Homewood, Illinois: Richard D. Irwin, 1961. Online: https://doi.org/10.1111/j.1467-6435.1961.tb02365.x

Bartal, Tamás András, 'Az Internet története', 2004. Online: www.agr.unideb.hu/ agocs/ informatics/05_h_ecdl/ECDLweb/ecdlweb.uw.hu/m7-02.html

Bartczak, Krzysztof and Fernando Garcés de los Fayos, 'The European Economic Area (EEA), Switzerland and the North', 2018. Online: www.europarl.europa.eu/factsheets/en/ sheet/169/der-europaische-wirtschaftsraum-ewr-die-schweiz-und-der-norden

Beck, Ulrich, Was ist Globalisierung? Frankfurt: Suhrkamp, 1997.

Bhagwati, Jagdish, In Defence of Globalization. New York: Oxford University Press, 2004.

Bilton, Tony et al., Introductory Sociology. London: Macmillan, 1996. Online: https://doi. org/10.1007/978-1-349-24712-7

Czuczai, Jenő and Lajos Ficzere (eds), Európa A-tól Z-ig. Budapest: Eötvös Lóránd Tudományegyetem, 1997.

Csáki, György, Nemzetközi gazdaságtan. Budapest: Napvilág Kiadó, 2017.

Cséfalvay, Zoltán, Globalizáció 1.0. Budapest: Nemzeti Tankönyvkiadó, 2004.

Dollar, David, Globalization, Poverty, and Inequality since 1980. Development Research Group, World Bank, 2001. Online: https://doi.org/10.1093/wbro/lki008

Káldyné Esze Magdolna et al., Integrálódó Európa. Budapest: Perfekt Gazdasági Tanácsadó, Oktató és Kiadó, 2009.

European Commission, 'What is the euro area?', 2019. Online: https://ec.europa.eu/ info/business-economy-euro/euro-area/what-euro-area_en

Forgó, Sándor, Médiaismeret. Eger: BVB Nyomda és Kiadó Kft., 2010.

Gereff, Gary, 'International Trade and Industrial Upgrading in the Apparel Commodity Chain'. Journal of International Economics 48, no 1 (1999), 37-70. Online: https://doi. org/10.1016/s0022-1996(98)00075-0

Giddens, Anthony, The Consequence of Modernity. Cambridge: Polity Press, 1990.

Halmai, Péter, Krízis és növekedés az Európai Unióban. Budapest: Akadémiai Kiadó, 2014. 
Hangodi, Lajos, 'A balassagyarmati vezetékes hírközlés technikatörténete: telegráf távíró és telefon - távbeszélő', s. a. Online: www.balassagyarmat.eu/Hangodi_technikatortenet.html

Held, David et al., Global Transformations. Politics, Economics and Culture. Cambridge: Polity Press, 1999.

Held, David et al., Global Transformations. Cambridge: Polity Press, 2005.

Horváth, Jenő, 'Az európai integráció története: 1945-2000', in Európai integrációs alapismeretek, ed. by András Blahó. Budapest: Aula Kiadó, 2003, 67-113.

Kengyel, Ákos, 'Az Európai Unió politikái', in A globális és regionális integráció gazdaságtana, ed. by Tibor Palánkai et al. Budapest: Akadémiai Kiadó, 2011, 217-254.

Kolmer, Bence, 'Az okos eszközök megjelenése mindennapi életünkben', 2014. Online: https:// prezi.com/cux9hf3xm6lm/az-okos-eszkozok-megjelenese-mindennapi-eletunkben/

Kurya, Bence, A multipoláris világrend fejlődése, kialakulása, és jövője. Miskolc: Miskolci Egyetem, 2014.

Lechner, Frank J and John Boli (eds), The Globalization Reader. Malden: Blackwell, 2005.

Levitt, Theodore, 'The Globalization of Markets'. Harvard Business Review no 3 (1983), 92-102.

Molnár, Zsófia, 'Közép-európai Szabadkereskedelmi Megállapodás', 2013. Online: https:// prezi.com/zm4y-zkjygvh/kozep-europai-szabadkereskedelmi-megallapodas/

OECD, 'Organisation for Economic Co-operation and Development', 2018. Online: www. oecd.org/about/

Orbán, Annamária, 'Globalizáció, urbanizáció, fenntartható fejlődés’, s. a. Online: https://slideplayer.hu/slide/2221258/

Origo, 'Bankszámlatöri, hogy ne kapjon egyest', 01 November 2016. Online: www.origo. hu/gazdasag/20161028-a-bankszamlak-evolucioja.html

Palánkai, Tibor et al., A globális és regionális integráció gazdaságtana. Budapest: Akadémiai Kiadó, 2011. Online: https://doi.org/10.1556/9789630598385

Robertson, Roland, Globalization: Social Theory and Global Culture. London: Sage Publication, 1992.

Sasné Grósz Annamária, 'A kulturális értékek, mint a globalizációs törekvések akadályai', 2004. Online: http://rs1.szif.hu/ pmark/publikacio/Netware/tema.html

Scholte, Jan Aart: What Is Globalization? The Definitional Issue - Again. United Kingdom, University of Warwick, 2002.

Simai, Mihály, 'A globalizáció főbb tendenciái és kérdőjelei a XX. század végén'. Tudományos Közlemények no 1 (2000), 9-18.

Simai, Mihály, 'Globalizáció és regionális együttműködés a XXI. század elején', in Európai integrációs alapismeretek, ed. by András Blahó. Budapest: Aula Kiadó, 2003, 41-66.

Steinbach, Sandro, 'Baltic Free Trade Agreement', 2012. Online: https://stats.oecd.org/ glossary/detail.asp?ID=174

Szentes, Tamás, 'Globalizáció, kölcsönös függések a világgazdaságban’, in Világgazdaságtan, ed. by András Blahó et al. Budapest: Akadémiai Kiadó, 2007, 31-56.

The Economist, 'Britain's Fallen Star', 21 February 2009, 56-57.

Waters, Malcom, Globalization. London: Routledge, 1995.

Wolf, Martin, Why Globalization Works. New Haven: Yale University Press, 2005. 